Reprod. Nutr. Dévelop., 1988, 28 (4 B), $1031-1046$

\title{
Control of testis function in fish: in vitro studies of gonadotropic regulation in the trout (Salmo gairdneri)
}

\author{
F. LE GAC, M. LOIR
}

Laboratoire de Physiologie des Poissons, I.N.R.A Campus de Beaulieu, 35042 Rennes, France.

Summary. This paper briefly describes recent data we have obtained on gonadotropin $(\mathrm{GtH})$ regulation of the testicular somatic cells in relation to spermatogenesis and sperm production (spermiation).

Throughout the spermatogenetic cycle, the number of testicular $\mathrm{GtH}$ binding sites was maximum before and during spermiation. While testicular sensitivity to s-GtH for 11 -ketotestosterone (11 KT) secretion was maximum at the beginning of spermiation, for $17 \alpha, 20 \beta$-dihydroprogesterone $(17 \alpha, 20 \beta$-OH-P) secretion, sensitivity was maximum during full spermiation.

On the other hand, production of androgen binding protein by testicular explants was not influenced by $\mathrm{GtH}$. Similarly, no effect of $\mathrm{GtH}$ was seen on testicular aromatase activity.

Testosterone and $11 \mathrm{KT}$ production by Leydig cell populations in culture could be stimulated by s-GtH. Whether s-GtH was present or not, the ability of these cells to secrete androgens decreased throughout the culture period, while $17 \alpha, 20 \beta-\mathrm{OH}-\mathrm{P}$ production increased.

This data shows that the responsiveness to $\mathrm{GtH}$ varies with the cell type concerned (Leydig cell or Sertoli cell) and with the stage of the reproductive cycle. The work also raises questions dealing with the hormonal and local regulation of testicular functions in salmonids. What controls the androgen to protestagen shift that occurs at spermiation? Which cells are the testicular target for $\mathrm{GtH}$ ? Are other pituitary factors and/or paracrine regulation involved in the control of testis function?

\section{Introduction.}

The testis of seasonally breeding teleost fish such as salmonids displays at least two peculiarities:

- germ cells differentiate almost synchronously during the maturation cycle. In trout, this cycle has been divided into 9 stages (Billard and Escaffre, 1975). However, it should be noted that the synchrony between males of the same strain is rather loose. In fact there is a noticeable individual variability in the time at which spermiation begins and in the duration of the spermiation period. Furthermore, the breeding season differs (winter or spring or late summer) for the various strains of trout we have used;

- until recently, a single gonadotropic hormone $(\mathrm{GtH})$ was assumed to control the testis function. This hormone was called « maturational » $\mathrm{GtH}$ because it could also induce the final maturation of fish oocytes. 
For these two reasons the teleost testis constitutes a particularly interesting model for studying extratesticular control of male gonad activity as well as local regulation by spermatogenic cells.

Since the early studies on hypophysectomized animals (Pickford and Atz, 1957 ; Yamazaki and Donaldson, $1969 ; \mathrm{Ng}$ and Idler, 1980), the prominent role of maturational $\mathrm{GtH}$ in testis regulation has been demonstrated in several species of fish. $\mathrm{GtH}$ preparations maintain or restore various stages of spermatogenesis and steroidogenesis in hypophysectomized animals (see recent reviews by Billard et al., 1982 ; Lofts, 1987 ; Nagahama, 1987 ; Fostier, Le Gac and Loir, 1987). This hormone stimulates androgen and progestagen production by testicular tissue in vitro (Huang and Chang, 1980; Ueda et al., 1984 ; Schulz and Blum, 1987; Le Gac and Fostier, 1987).

However, fish physiologists do not yet understand how a single gonadotropin can control the function of the various somatic cells localized in the different testicular compartments, i.e. Leydig cells in the interstitial tissue and Sertoli cells inside the lobules. A better understanding of these phenomena requires investigation of the different testicular cell types, their function, their interactions as well as their receptivity to pituitary signals.

In this report two testicular activities, androgen binding protein (ABP) and aromatase have been studied as potential markers of Sertoli cell function. To get an insight into steroidogenesis, the production and secretion of androgens and progestagens have been investigated in two in vitro systems :

- short-term incubation of testicular explants ;

- long-term primary cultures of isolated « round testis cells» and of populations enriched in Leydig cells or Sertoli cells.

Firstly, the influence of salmon gonadotropin (s-GtH; Breton, Prunet, Reinaud, 1978) was investigated at different stages of the male reproductive cycle.

We present here a few representative experiments and discuss our data with respect to present knowledge concerning the control of testicular function in salmonids and mammals.

\section{$A B P$, and aromatase activities.}

$A B P$. - Our study has revealed the presence of a steroid binding activity in trout testicular cytosol, seminal plasma, and testicular explant incubation media. Tritiated steroid binding was demonstrated and characterized by 3 methods: equilibrium dialysis, steady-state polyacrylamide gel electrophoresis (Ritzen et al., 1974) and separation of bound and free steroids by DEAE biogel (Johnson et al., 1985). Several binding characteristics (Foucher and Le Gac, submitted for publication in J. Steroid. Biochem.) are similar to those of ABP secreted by Sertoli cells in mammals (See review by Tindall and Means, 1980) : (i) the trout factor migrates like rat $A B P$ in polyacrylamide gel electrophoresis; (ii) it presents a higher affinity for androgens ( $\mathrm{Kd}=2.510^{-9} \mathrm{M} / \mathrm{L}$ for testosterone) than for other sex-steroids and does not bind corticosteroids; (iii) the protein-hormone complex dissociates very rapidly (half life $<2 \mathrm{~min}$ ). 
In vitro production of the binding activity by minced testes argues for testicular synthesis of ABP. We have started to investigate the effect of s- GtH on ABP production by testicular explants. Using various experimental conditions we have not been able to show a significant effect of the purified gonadotropin on binding protein accumulation in culture medium (fig. 1). Crude pituitary extracts did not have a significant effect either on ABP while they were highly stimulatory on androgen secretion in the same experiments.

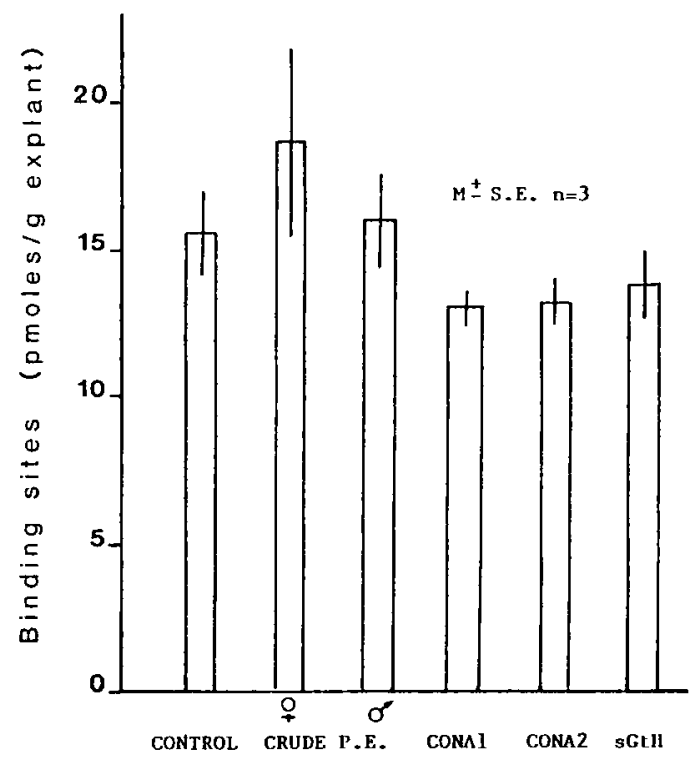

FIG. 1. - Accumulation of ABP activity in incubation media of trout testicular explants in the absence (control) or the presence of $100 \mathrm{ng} / \mathrm{m} /$ of purified salmon $\mathrm{GtH}(\mathrm{s} . \mathrm{GtH}$ ), $50 \mu \mathrm{g} / \mathrm{m} /$ of crude female or male pituitary extracts (crude P.E.), or pituitary extracts partially separated into two fractions by chromatography on concanavaline $A$; CONA 1 : fraction eluted ; CONA 2 : fraction retained on the column. Trout testis were perfused to avoid blood contamination; tissues were minced in $8 \mathrm{~mm}^{3}$ blocs, washed 3 times and 15 to 20 explants were incubated for $24 \mathrm{~h}$ in culture medium (BME GIBCO) buffered with hepes $(\mathrm{pH} \mathrm{7,7)}$ and complemented with amino-acids and vitamins (Foucher and Le Gac submitted to J. Steroid Biochem).

Aromatase. - We have investigated the capacity for trout testis to produce oestradiol. The enzyme responsible for the conversion of androgens into oestrogens was demonstrated for the first time in teleost testis (Fostier, Le Gac and Loir, 1987) although it had been previously found in an elasmobranch (Callard et al., 1985). Metabolism of tritiated testosterone by a microsomal fraction obtained from testicular tissue at the beginning of spermatogenesis was studied. At the end of the experiment the tritiated oestradiol and oestrone were purified then identified by successive crystallisation to constant specific activity (data not shown).

When testicular explants were incubated with increasing concentrations of s-GtH, oestradiol secretion, measured by RIA, increased in a dose-dependent manner (fig. 2A). Addition of high concentrations of testosterone alone (50 and 
$500 \mathrm{ng} / \mathrm{ml}$ ) also stimulated $\mathrm{E} 2$ accumulation in the incubation media (fig. 2B). However, in the presence of the highest testosterone level, no significant effect of $\mathrm{s}-\mathrm{GtH}$ was obtained (fig. 2B).

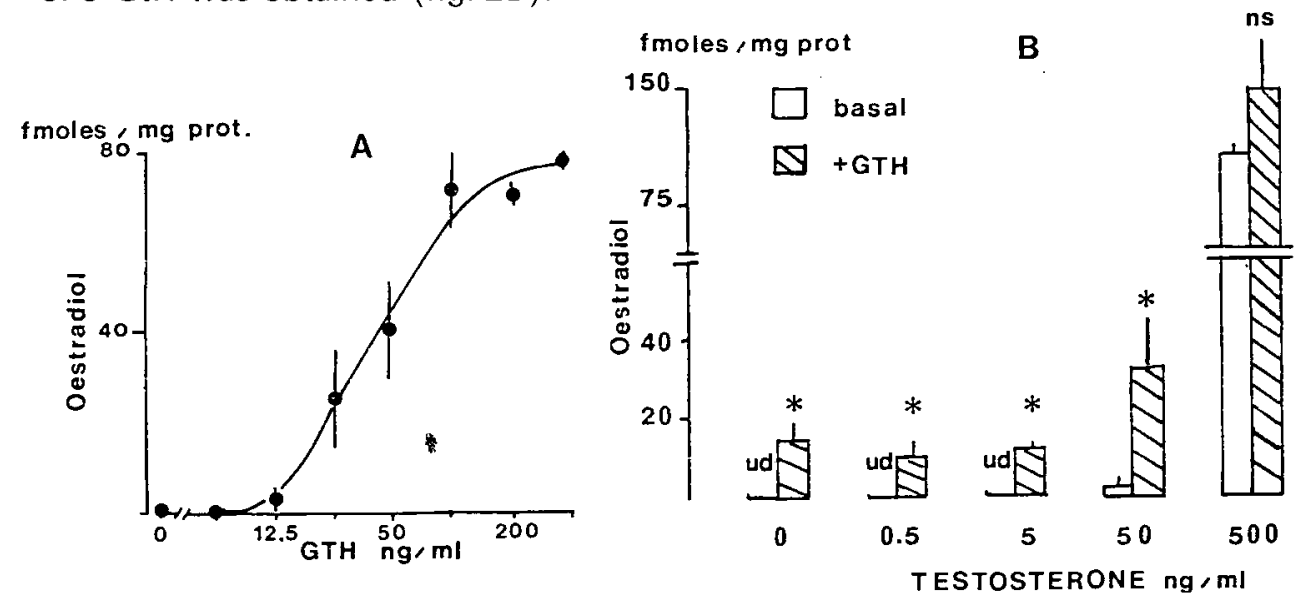

FIG. 2. - Oestradio/ secretion by trout testicular explants, incubated $\left(24 \mathrm{~h}, 14{ }^{\circ} \mathrm{C}\right)$ with increasing concentrations of $s-G t H(A)$, or increasing concentrations of testosterone, in the presence or the absence of $20 \mathrm{ng} / \mathrm{ml} \mathrm{s-GtH}$ (B). (ud): undetectable: $\left({ }^{*}\right)$ : significantly and (ns): nonsignificantly different from adjacent point obtained in absence of $\mathrm{GtH}$ (variance analysis Newman-Keuls test).

Furthermore, when in other experiments explants were preincubated with $\mathrm{s}-\mathrm{GtH}(1.00 \mathrm{ng} / \mathrm{ml})$, then used to measure ${ }^{3} \mathrm{H}$-testosterone metabolisation into ${ }^{3} \mathrm{H}$-oestrogens, no effect of the maturational gonadotropin was observed. It can therefore be hypothesized that this hormone has no direct action on aromatase, and that the previously observed effect of s-GtH on oestradiol secretion (fig. 2A) could be simply due to an increase of androgen precursors in the incubated testis explants.

\section{Steroidogenesis and testicular receptivity to $\mathrm{GtH}$.}

Evolution of testicular tissue sensitivity to $\mathrm{GtH}$ and $\mathrm{GtH}$ receptors in relation to the spermatogenic stage.

In salmonids, 11 -ketotestoterone $(11 \mathrm{KT})$ is possibly involved in the regulation of the last stages of spermatogenesis and in the initiation of milt production. In turn, $17 \alpha$-hydroxy-20 $\beta$-dihydroprogesterone $(17 \alpha, 20 \beta$-OH-P) seems involved in increased semen production during spawning (see review by Fostier, Le Gac and Loir, 1987).

To better understand the role of the gonadotropin in the evolution of steroid concentrations during the reproductive cycle, we have studied, in vitro, the testicular production of these two major steroids in response to GtH at different stages of the spermatogenic cycle.

Results concerning $11 \mathrm{KT}$ are summarized in figure $3 \mathrm{~A}$ to $\mathrm{C}: 11 \mathrm{KT}$ concentration in blood plasma increased toward the end of the cycle and reached high levels just before the beginning of spermiation (fig. 3A). During this period, plasma GtH levels did not exhibit high amplitude variations (fig. 3B). 

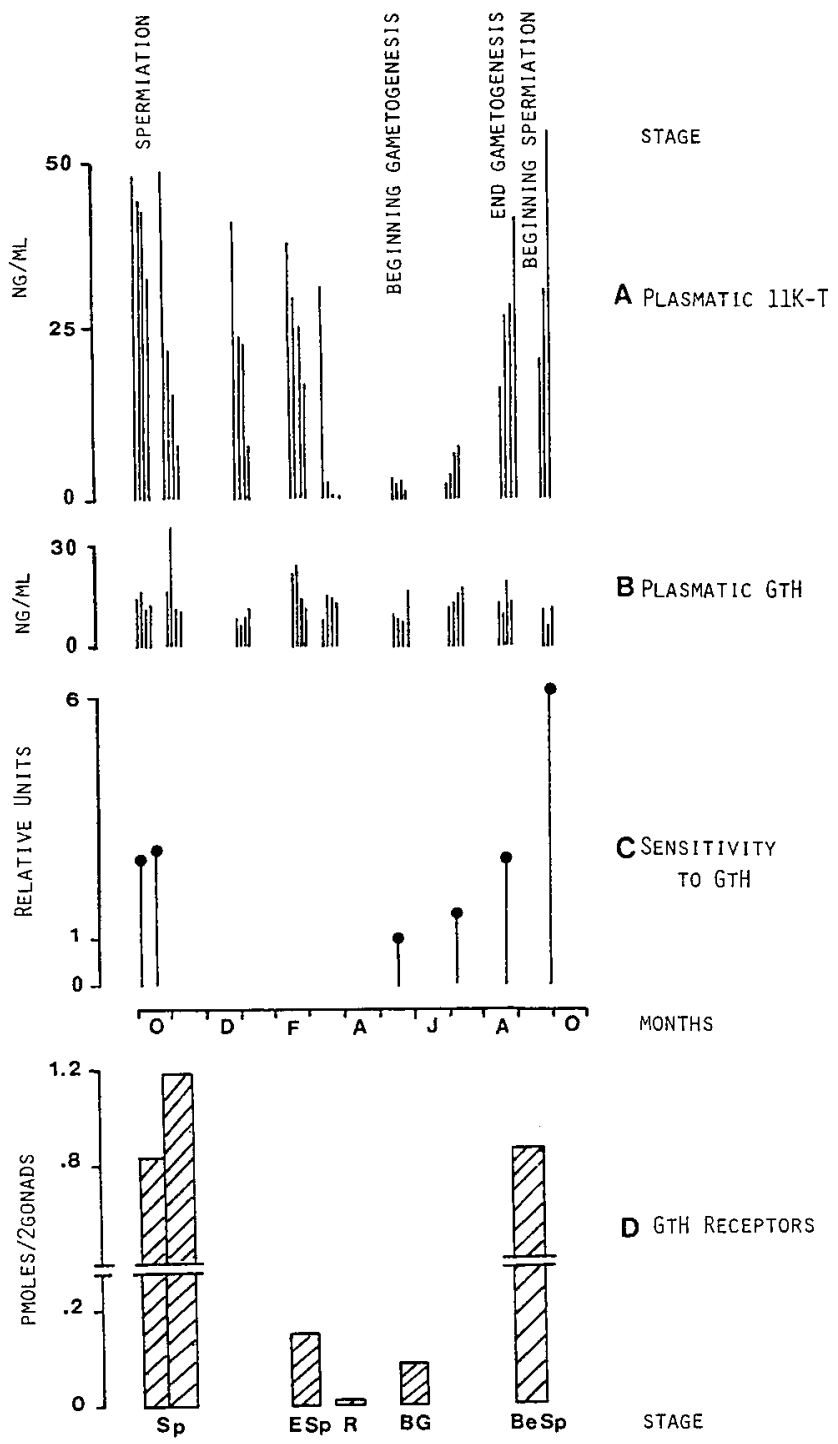

FIG. 3. - Evolution of several parameters of the male rainbow trout reproductive function during the end of one spermatogenic cycle (October to March) and during the beginning of the next cycle (May to October) : $A$ : individual values of 11 Cetotestosterone plasmatic concentrations. $B$ : individual values of $\mathrm{GtH}$ plasmatic concentrations. $C$ : sensitivity to $\mathrm{GtH}$ of $11 \mathrm{KT}$ testicular secretion. Relative sensitivity is represented here by the ratio: ED50 in May (beginning of gametogenesis)/ED50 at various stages. $D$ : separate experiment showing the number of GtH high affinity binding sites measured in testicular membrane preparations at various spermatogenetic stages (see text for details).

$\mathrm{Sp}$ : Spermiation (2 different times during the period of full spermiation, which lasts for 2 to 3 months) ; ESp : end of spermiation ; R : regression ; B.G. : beginning of gametogenesis ; Be.Sp. : before spermiation. 
Spermatogenetic stages of the gonads were determined after histology. For some of the fish, testicular steroid production in response to $\mathrm{GtH}$ was studied during in vitro incubation. Minced testicular tissue was incubated in the presence of 10 different concentrations of s-GtH $(0,78$ to $400 \mathrm{ng} / \mathrm{ml})$ for $20-24 \mathrm{hrs}$ at $12{ }^{\circ} \mathrm{C}$, and steroids were measured in the incubation media, using specific RIA. We determined the GtH concentration necessary to induce half maximum stimulation at different stages (ED $50 \mathrm{i}$ ) and calculated the relative sensitivity to GtH : ED 50 in may (maximum ED 50 obtained)/ED $50 \mathrm{i}$.

With respect to the $11 \mathrm{KT}$ response, the relative sensitivity to $\mathrm{s}-\mathrm{GtH}$ was found to be minimum at the beginning of gametogenesis and maximum at the beginning of spermiation (fig. 3C).

$\mathrm{GtH}$ receptors have been characterized on membrane-enriched preparations of trout testicular tissue. Binding sites present a high affinity for maturational $\mathrm{GtH}$ ( $\mathrm{Ka}=2 \times 10^{9} \mathrm{M}^{-1}$ ) compatible with the concentrations of $\mathrm{GtH}$ biologically active on steroidogenesis (Le Gac et al., 1985, 1988). In a separate experiment, precise stages of testis development were determined by histology. Testicular membranes were prepared then pooled ( 2 to 8 gonads/pool) according to the spermatogenic stage. Affinity constant and number of $\mathrm{GtH}$ receptors were determined for each stage by saturation experiments and scatchard analysis. The affinity did not change significantly during the gametogenic cycle. The number of $\mathrm{GtH}$ binding sites was very low in regressed testis. It increased during gametogenesis and was maximum just before and during spermiation (fig. 3D) (Le Gac and Fostier, 1987).

Therefore, increased sensitivity of testicular tissue to s-GtH appears to be concomitant to a rise in testicular high affinity $\mathrm{GtH}$ binding site numbers. These events might favour an increase in plasma levels of steroids at the end of the cycle.

In this study, plasma $11 \mathrm{KT}$ levels increased before $17 \alpha, 20 \beta-\mathrm{OH}-\mathrm{P}$ concentrations (data not shown), which were elevated during full spermiation as previously described by Baynes and Scott (1985). Similarly, as shown in table 1,

TABLE 1

Differential sensitivity of trout testis to $\mathrm{GtH}$ expressed by the $\mathrm{GtH}$ ED $50 \mathrm{in} \mathrm{ng} / \mathrm{ml}$ ) at two different stages of milt production and for two secreted steroids.

\begin{tabular}{lrr}
\hline & \multicolumn{2}{c}{ Steroid response considered } \\
\cline { 2 - 3 } & $11 \mathrm{KT}$ & $17 \alpha, 20 \beta-\mathrm{OH}-\mathrm{P}$ \\
\cline { 2 - 3 } Stage (a) & & $\mathrm{GtH}-\mathrm{ED} 50(\mathbf{b})$ \\
Initiation of spermiation & $6 \mathrm{ng} / \mathrm{ml}$ & $27 \mathrm{ng} / \mathrm{ml}$ \\
Full spermiation & $13 \mathrm{ng} / \mathrm{ml}$ & $3 \mathrm{ng} / \mathrm{ml}$ \\
\hline
\end{tabular}

(a) The stage of milt production was determined by measuring the sperm volume and a posteriori by histological observation of the testis (proportion of empty lobules). (b) Testicular explants were incubated with increasing $\mathrm{GtH}$ concentrations. $11 \mathrm{KT}$ and $17 \alpha, 20 \beta-\mathrm{OH}-\mathrm{P}$ were measured in the incubation media ; $E D 50$ is the $\mathrm{GtH}$ concentration inducing $50 \%$ of the maximal stimulation (One fish at each stage. One representative experiment). 
maximum sensitivity to $\mathrm{GtH}$ (minimum $\mathrm{ED} 50$ ) for $17 \alpha, 20 \beta-\mathrm{OH}-\mathrm{P}$ production by testis explants was reached later (during full spermiation) than for $11 \mathrm{KT}$ production. These data suggest a progressive change in the steroidogenic pathways during this stage in favour of $17 \alpha, 20 \beta-\mathrm{OH}-\mathrm{P}$ production. So far, this change cannot be explained by the evolution of plasma GtH concentration or of gonadal $\mathrm{GtH}$ receptor number during the spermiation period.

First data obtained with cultures of trout testis cells.

The method used to dissociate trout testis at various stages of maturation, to separate Leydig and Sertoli cells and to culture them for 10 to 15 days has already been presented elsewhere (Loir, 1988). It is summarized in figure 4 . In " round testicular cell » suspensions, somatic cells were mixed with round germ cells; most of the spermatozoa had been eliminated. In terms of somatic cell composition, the Leydig cell populations and Sertoli cell populations prepared from maturing and mature (spermiating) tests were at least $95 \%$ pure i.e. they contained regularly less than $5 \%$ of either Sertoli cells or Leydig cells respectively (fig. 7). As shown by the morphological and ultrastructural data and profiles of steroid secretion, these cells remained viable and maintained a differentiated activity during several days in culture.

Progesterone, $17 \alpha-\mathrm{OH}$ progesterone (17 $\alpha$-OHP), $17 \alpha, 20 \beta$-OHP, testosterone and $11 \mathrm{KT}$ were assayed in culture medium, after extraction, by specific radioimmunoassays. The main crossreactivities for these steroid radioimmunoassays with other progestagens and androgens were always under $5 \%$ (see Loir, 1988).

\section{a) Changes in the steroidogenic pathway during culture.}

Progesterone $(P)$ secretion by «round testicular cell » populations did not decrease throughout culture duration (figs. 5 and 6 ); the same result was obtained with Leydig cell populations (not shown). 17 $\alpha$-OH-P (fig. 5) and $17 \alpha, 20 \beta$-OH-P (fig. 6 ) output increased until 7-8 days in culture then either remained stable or decreased slowly according to the spermatogenic stage and/or animal.

The basal and $\mathrm{GtH}$-stimulated $11 \mathrm{KT}$ (figs. 5 and 6 ) and testosterone (not shown) secretion always decreased progressively and after 10-12 days they were nearly undetectable (figs. 5 and 6). This decrease in androgen secretion occurred either in the presence or the absence of added lipoprotein-bound cholesterol and whether the Leydig cells were purified or cultured with other somatic testicular cells. It was independant of the testis maturational stage. Furthermore, trout serum, which increased basal and $\mathrm{GtH}$-stimulated androgen secretions at the beginning of culture, did not prevent their following decrease (fig. 5). Because the fall of the androgen output was always related to an increase in progestagens, it can be excluded that it resulted from an impairment in cell viability.

22-hydroxycholesterol, which enables measurement of the maximal rate of steroidogenesis in vitro (Risbridger et al., 1986), was added to round testis cell and Leydig cell cultures. It has appeared that the maximal ability of the steroidogenic cells to secrete testosterone decreased regularly and was reduced 
- Dissociation

- Removal of spermatozoa

- Separation : 1solated cells cell clusters

- Separation : Leydig cells Sertoli cells
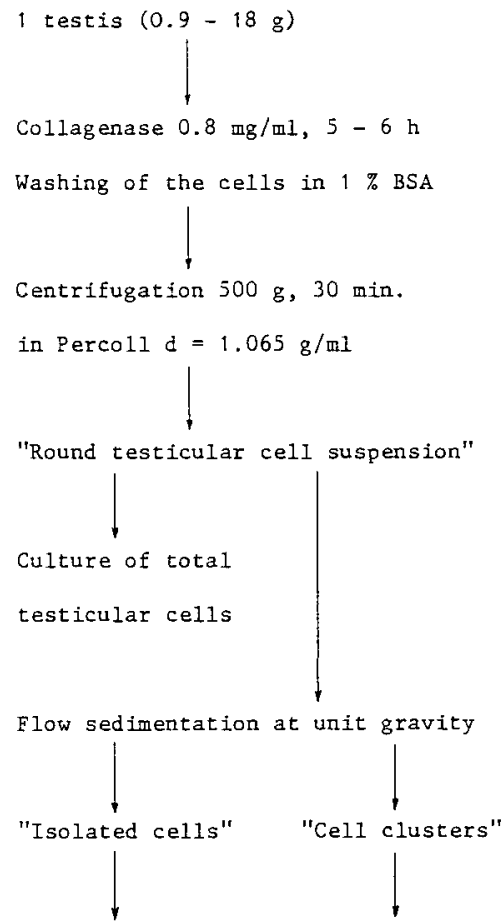

Centrifugation $800 \mathrm{~g}, 1 \mathrm{~h}$

Percoll gradients $d: 1.016$ to $1.070 \mathrm{~g} / \mathrm{m} 1$

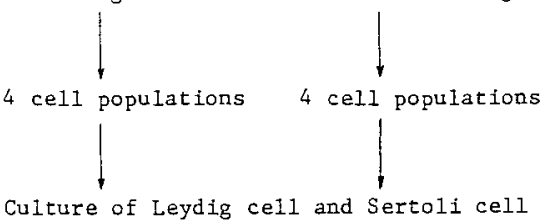

populations

FIG. 4. - Scheme of preparation of trout Leydig cell and Sertoli cell populations. All operations were carried out at $12{ }^{\circ} \mathrm{C}$, in sterile conditions. An average of 32 to $34 \mathrm{~h}$ separated castration from seeding of the cells.

to zero after about 10 days in culture. Several hypothese could be considered to explain the shift from androgens to progestagens observed in our culture conditions. We will only note two points. Firstly, ultrastructural observations suggest that some process of dedifferentiation of the Leydig cells was initiated 5-6 days after seeding, if not sooner (Loir, 1987). Secondly, the shift in steroid output we observed in vitro mimics that which takes place at the period of spermiation (see above). In this respect, the data obtained with 22-hydroxycholesterol suggest that, at least in our in vitro conditions, the decrease in androgen 

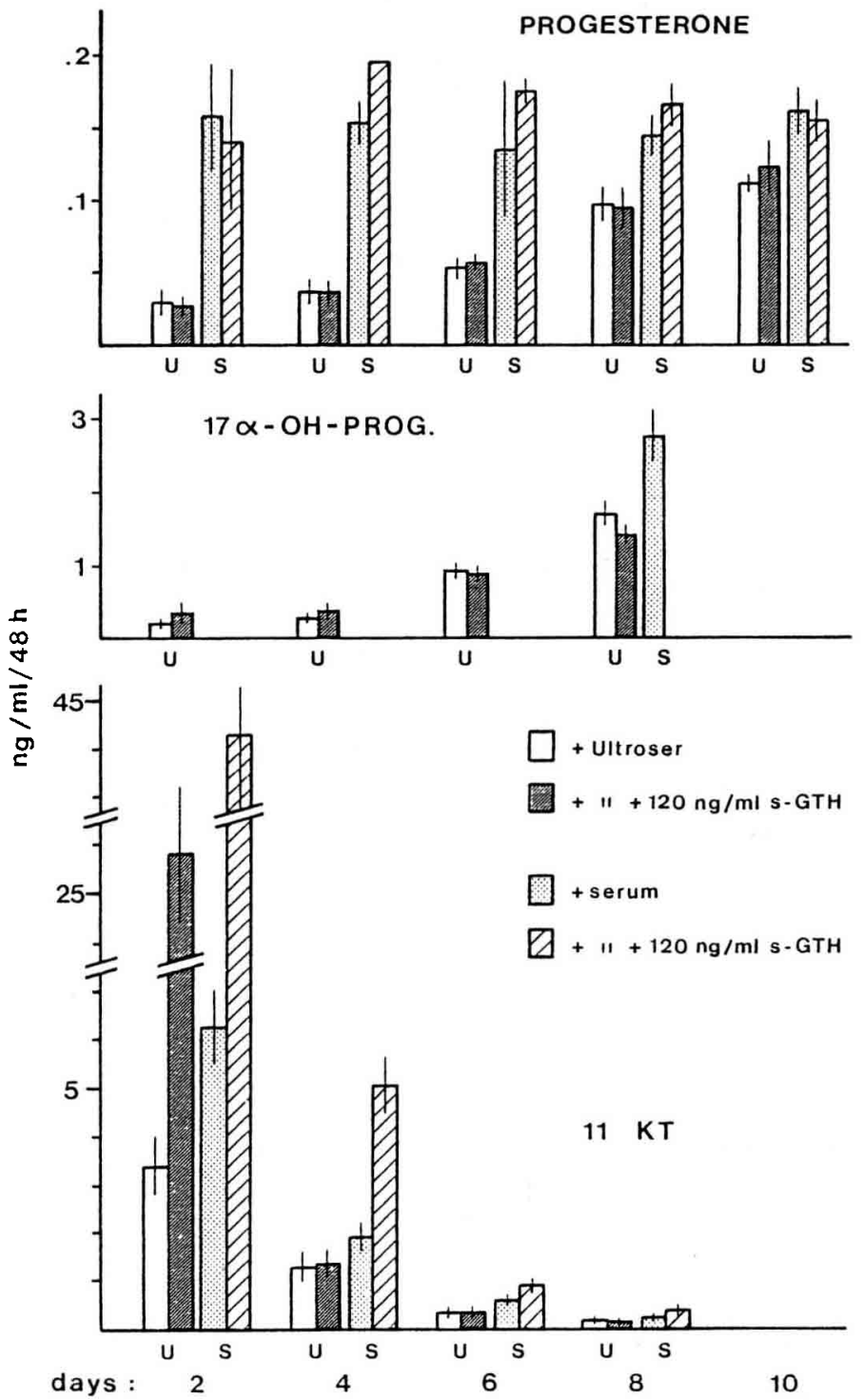

FIG. 5. - Changes in the basal and s-GtH stimulated progesterone, $17 \alpha$-OH-progesterone and $11 \mathrm{KT}$ secretions by a round testicular cell population $\left(4.7 \times 10^{6}\right.$ round cells $\left./ \mathrm{ml}\right)$ cultured in the presence either of $2 \%$ ultroser or $5 \%$ young trout serum. One representative spermiating testis. Mean of 3 wells \pm standard error.

production might result from a progressive shutting down of the enzyme activities involved in the conversion of $17 \alpha-\mathrm{OH}-\mathrm{P}$ into androgens. In addition it might be due to disturbances induced by in vitro methods as previously proposed for 

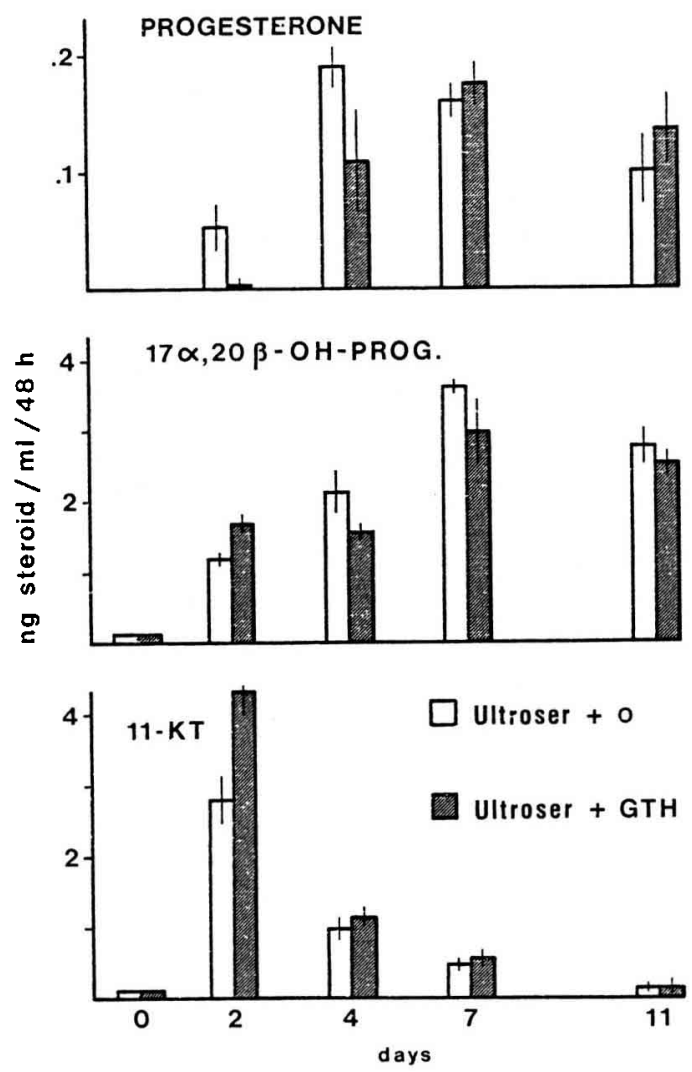

FIG. 6. - Changes in the basal and s-GtH-stimulated $(100 \mathrm{ng} / \mathrm{ml})$ progesterone, $17 \alpha, 20 \beta-O H-P$ and $11 \mathrm{KT}$ secretions by a round testicular cell population $\left(4.4 \times 10^{6}\right.$ round cells $\left./ \mathrm{ml}\right)$ cultured in the presence of $2 \%$ ultroser. One representative testis at the beginning of spermiation. Mean of 3 wells \pm standard error.

mammalian testis cells in culture : disruption of cellular interactions, degradation or accumulation of regulator molecules (Verhoeven et al., 1986), suppression of adrenergic innervation (Pointis and Latreille, 1987) and suppression of associated germ cells (Parvinen, Nikula and Huhtaniemi, 1984).

b) Responsiveness of steroidogenic cells to s-GtH.

Round testicular cells. - The secretion of progesterone and $17 \alpha-\mathrm{OH}-\mathrm{P}$ (fig. 5 ) by the testis cells was never observed to be stimulable by s-GtH. In fact, in some experiments a slight depression of $P$ secretion was observed which could be due to an increase in progesterone conversion.

After 1 to 2.5 days in culture, the output of $11 \mathrm{KT}$ (figs. 5 and 6), $17 \alpha, 20 \beta$-OH-P (fig. 6 ), testosterone (not shown) by cells prepared from maturing and mature testes were stimulated by s-GtH. At the end of spermiation period the cells were not sensitive to the hormone. 
When testis cells were cultured in the presence of $2 \%$ steroid-free Ultroser (Serum substitute, IBF, France), the $11 \mathrm{KT}$ (figs. 5 and 6) and testosterone (not shown) secretions were stimulable by 100 or $120 \mathrm{ng} \mathrm{s-GtH/ml} \mathrm{for} \mathrm{only} 3$ to 5 days. However, when they were cultured in the presence of $5 \%$ young trout (50 to $70 \mathrm{~g}$ ) serum, these secretions could be stimulated by $\mathrm{GtH}$ during a longer period : 6 days (fig. 5 ).

This loss of androgen secretion sensitivity to $\mathrm{GtH}$ could be the expression of defects induced by in vitro conditions. On the other hand, $\mathrm{GtH}$ was present all along the culture period. Therefore the loss of receptivity to this hormone could be due to desensitization of the target cells, as shown in mammals in the case of prolonged stimulation by high doses of gonadotropin (see Tahka, 1986). This hypothesis is going to be checked.

Leydig cells. - Cell populations enriched in Leydig cells (identified by their $3 \beta$-HSD activity and their fibroblastoid morphology after spreading) secreted $17 \alpha-\mathrm{OH}-\mathrm{P}, 11 \mathrm{KT}$ (fig. 7, cell population 2), testosterone and $17 \alpha, 20 \beta-\mathrm{OH}-\mathrm{P}$ (not shown). Testosterone and $11 \mathrm{KT}$ secretions were conspicuously stimulated by $\mathrm{s}-\mathrm{GtH}$ ( $\mathrm{GtH}$-stimulated/basal ratio after 2 or 2.5 days in culture : 4 to 16 for $11 \mathrm{KT}$ and 2 to 3 for testosterone). $17 \alpha-\mathrm{OH}-\mathrm{P}$ secretion was not sensitive to $\mathrm{s}-\mathrm{GtH}$ as already mentioned for total testis cells. At the present time we do not know if $17 \alpha, 20 \beta$-OH-P secretion was $\mathrm{s}-\mathrm{GtH}$ sensitive.

Sertoli cel/s. - Low levels of $11 \mathrm{KT}$ were measured when cell populations enriched in Sertoli cells were cultured for 2 or 2.5 days (fig. 7 cell population 4 ),

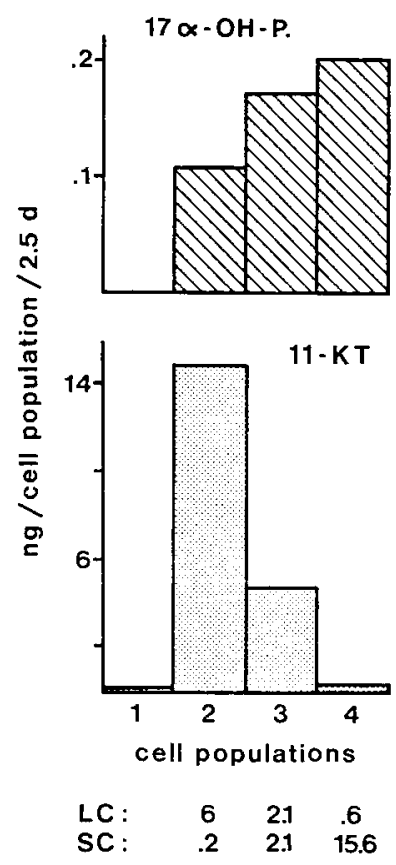

FIG. 7. - s-GtH-stimulated $(120 \mathrm{ng} / \mathrm{ml}) 17 \alpha-O H-P$ and $11 K T$ secretions by the 3 cell populations obtained after centrifugation of the "cell cluster population" onto a percoll density gradient. One representative spermiating testis. 2.5 days in culture. Number of Leydig cells (LC) and Sertoli cells (SC) in every population : $\times 10^{6}$ cells. Leydig cell population : popuIation 2. Sertoli cell population : population 4. There were no Leydig or Sertoli cells in population 1, only some spermatozoa and some scarce spermatogonia and myoid cells were present.

SC: $\quad .2 \quad 2.1 \quad 15.6$ 
and this secretion was s-GtH-stimulable. However, we assume that this secretion could be ascribed to the contaminating Leydig cells. Indeed in the cell populations 2, 3 and 4 the secreted amounts of $11 \mathrm{KT}$ and the numbers of Leydig cells varied concurrently (fig. 7). On the contrary, the secretion of $17 \alpha-\mathrm{OH}-\mathrm{P}$ by such populations was higher than that which could be secreted by contaminating Leydig cells (fig. 7) and in the cell populations 2, 3 and 4 it increased concurrently with the number of Sertoli cells. This observation can be interpreted in several ways ; for example, Sertoli cells might be able to secrete $17 \alpha$-OH-P. This secretion was never sensitive to $\mathrm{s}-\mathrm{GtH}$.

\section{Discussion.}

In vivo and in vitro changes in steroïdogenesis. - Similar changes in steroidogenic pathways have been demonstrated both in vivo during early spermiation and in vitro during Leydig cell long-term culture. In both cases the change may be due to increased $17 \alpha-\mathrm{OH}-\mathrm{P}$ conversion in favour of $17 \alpha, 20 \beta-\mathrm{OH}-\mathrm{P}$ production and a decreased conversion of $17 \alpha-\mathrm{OH}-\mathrm{P}$ into androgens.

Recently Saad and Dépêche (1987) have shown that several steroidogenic enzymes (including 20 $\beta$-hydroxysteroïde dehydrogenase : $20 \beta$ - HSD and C17-C20 lyase) were under positive control by $\mathrm{GtH}$ (fig. 8 ). They did not find any $\mathrm{GtH}$ inhibition of the C17-C20 lyase that could have explained a decreased conversion of $17 \alpha-\mathrm{OH}-\mathrm{P}$ into androgens. However, Inano et al. (1967) have shown that the C17-C20 lyase of rat testicular microsomial fraction was inhibited by $17 \alpha, 20 \beta$ -OH-P. An increase in this progestagen secretion could therefore amplify the shift in biosynthetic pathway towards $17 \alpha, 20 \beta-\mathrm{OH}-\mathrm{P}$ production.

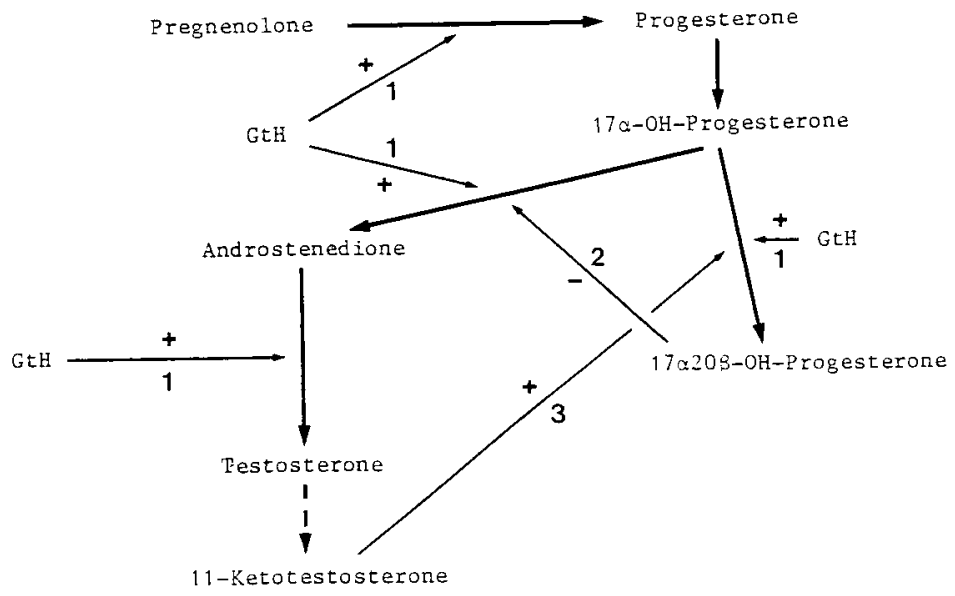

FIG. 8. - Simplified diagram of the major steroid biosynthetic pathway in the rainbow trout testis. [Modified from Dépêche and Sire (1982)].

Double arrows : putative sites of extra and intra-testicular control of enzymatic activities. $1:$ from Dépêche and Sire, 1982 and Saad and Dépêche, 1987. 2 : from Inano et al., 1967. 3 : from Leprêtre, 1985. 
However, the initiation of this phenomenon is still not understood. It could be due to $20 \beta$-HSD activation by the high levels of androgen found in vivo at the beginning of spermiation, or in vitro after a short time of testicular cell culture. Le Prêtre (1985) has presviously proposed that this enzyme is regulated by $11 \mathrm{KT}$ (fig. 8).

It could also result from a specific evolution of Leydig cells under the influence of the maturing spermatogenic cells. Such events, probably mediated by the Sertoli cells, have already been pointed out in mammals (Parvinen, Nikula and Huhtaniemi, 1984). In this respect the release of spermatozoa by testicular tissue during spermiation in vivo as well as the progressive elimination of spermatids and spermatozoa from the cell cultures in vitro, might take part in the concomitant evolution of $17 \alpha, 20 \beta-\mathrm{OH}-\mathrm{P}$ production by the somatic cells.

In vivo, germ cell differentiation itself might be in part responsible for the steroidogenic change since Ueda et al. (1984) have shown high $20 \beta$-HSD activity associated to mature spermatozoa. However, our Leydig cell culture results invalidate Nagahama's suggestion that the distribution of $20 \beta$-HSD in testis is limited only to sperm (Nagahama, 1987).

Which cells are target cells for GtH in the trout testis ? - We have shown that androgen secretions by enriched Leydig cell populations are rapidly and markedly enhanced by addition of $\mathrm{GtH}$ at physiological concentrations. Therefore, these cells can be considered as a major target cell for maturational $\mathrm{GtH}$ in the fish testis. On the other hand, $17 \alpha-\mathrm{OH}-\mathrm{P}$ secretion by isolated Sertoli cell populations was never observed to be sensitive to $\mathrm{GtH}$. Furthermore, in immature rats, $A B P$ secretion and aromatase activity have been shown to be specific Sertoli cell functions. If a similar situation exists in the teleost, the absence of $\mathrm{GtH}$ effect on these activities suggests that trout Sertoli cells might not be under maturational $\mathrm{GtH}$ control. Investigation of the presence of $\mathrm{GtH}$ receptors in purified Sertoli cells will be one way to test this hypothesis.

Are hypophysial hormones other than maturational GtH involved in testis regulation? - $\mathrm{ABP}$ and aromatase activity in immature rats are positively regulated by FSH (Dorrington et al., 1978; Tindall and Means, 1980). The absence of maturational $\mathrm{GtH}$ action on these activities in our experiments might result from inadequate experimental conditions (age of animals, stage of gametogenesis and non-hypophysectomized animals). However, our results could also be an indication that hormones other than maturational $\mathrm{GtH}$ are implicated in testicular regulation.

Two biochemically distinct GtH's have been recently purified from both salmon (Kawauchi et al., 1986) and carp (van der Kraak, Peter and Kawauchi, 1987) pituitaries. In carp, the two gonadotropins are claimed to present similar $\alpha$ subunits but different $\beta$ subunits. We propose, as a working hypothesis, that the second molecule, different from maturational $\mathrm{GtH}$, may be involved in fish Sertoli cell regulation. On the other hand, non-gonadotropin factors of hypophysial origin may intervene in testicular steroidogenesis. Results from Singh et al. (1987) have indicated that salmon growth hormone and possibly salmon prolactin, have direct stimulatory effects on teleost gonadal steroidogenesis. 
Preliminary experiments from our laboratory also indicate that addition of salmon growth hormone (purified by Le Bail et al., in preparation) to testicular cells in primary culture may influence steroidogenesis (Loir, Le Gac and Le Bail unpublished results).

\section{Conclusion.}

Our different studies led us to consider that factors other than changes in plasma maturational $\mathrm{GtH}$ levels are involved in the regulation of trout testicular function. Several questions need to be answered to allow further advancement in this field.

(i) Which testicular cells bear receptors for the maturational GtH? Does this hormone directly influence Sertoli cell function?

(ii) Do other hormones participate in regulation of the male gonad and do their circulating concentrations vary in relation to the spermatogenic cycle? Do they operate alone, or in synergy with $\mathrm{GtH}$ ? What would be their target cells in the gonad?

(iii) Possible paracrine and autocrine regulation in fish testis have been suggested by our results. At least two questions have already been raised:

- is somatic cell activity and responsiveness to $\mathrm{GtH}$ regulated by the differentiation of associated germ-cells?

- is there functional cooperation between the different testicular cell categories

for the maintenance of intragonadal levels of steroids?

Study of the different testicular cells in vitro, either isolated or in co-culture, should provide us with useful tools to answer at least some of these questions.

Recu en octobre 1987 Accepté en avril 1988.

Acknowledgments. - We Thank Dr B. Breton for kindly providing us with purified salmon gonadotropin and Drs A. Fostier and D. H. Garnier for their collaboration and helpful discussions during this work. We are grateful to J. Hall and $\mathrm{Dr} \mathrm{D}$. Webb for help with the English.

This work was supported by a grant from I.N.R.A. : ATP « Hormones hypophysaires et fonction de reproduction chez les Vertébrés ».

Résumé. Etude in vitro de la régulation de la fonction testiculaire par I'hormone gonadotrope chez la Truite (Salmo gairdneri).

Cet article décrit brièvement les résultats obtenus récemment dans notre laboratoire sur la régulation des cellules somatiques testiculaires par l'hormone gonadotrope $(\mathrm{GtH})$, en relation avec la spermatogenèse et la spermiation (études effectuées sur la truite arc-en-ciel, Salmo gairdneri).

Au cours du cycle spermatogénétique, le nombre de récepteurs testiculaires à la $\mathrm{GtH}$ est maximum juste avant et pendant la production de sperme (spermiation). La sensibilité testiculaire à la s-GtH, déterminée in vitro, est maximum au tout début de la spermiation quand on considère la réponse en termes de sécrétion de $11 \mathrm{KT}$, tandis que la sensibilité est maximum au cours de la pleine spermiation pour la sécrétion de $17 \alpha, 20 \beta-\mathrm{OH}$-P.

$\mathrm{Au}$ contraire, la production d'ABP (Androgen binding protein) par des explants testiculaires ne semble pas influencée par la s-GtH. De même, nous n'avons pas pu démontrer d'effet direct de la s-GtH sur l'aromatase testiculaire. 
La sécrétion de testostérone et de $11 \mathrm{KT}$ par des cellules de Leydig en culture, est stimulable par la s-GtH. Que cette hormone soit présente ou non, l'aptitude des cellules de Leydig à sécréter des androgènes diminue au cours de la période de culture (10 jrs) alors que simultanément la sécrétion de $17 \alpha, 20 \beta-\mathrm{OH}$-P augmente.

Nos résultats indiquent que l'aptitude à répondre à la $\mathrm{GtH}$ diffère selon les cellules considérées (cellules de Leydig ou cellules de Sertoli) et en fonction des stades de la spermatogenèse. $A$ la lumière de nos données, quelques questions relatives à la régulation hormonale et locale de la fonction testiculaire chez les salmonidés sont reposées: quels mécanismes contrôlent les évolutions opposées des androgènes et des progestagènes lors de la spermiation? Quelles sont, dans le testicule, les cellules cibles de la GtH ? D'autres facteurs, hypophysaires et/ou de nature paracrine, sont-ils impliqués dans le contrôle de la fonction testiculaire?

\section{References}

BAYNES S. M., SCOTT A. P., 1985. Seasonal variations in parameters of milt production and in plasma concentration of sex steroids of male rainbow trout (Salmo gairdneri). Gen. comp. Endocrinol., 57, 150-160.

BILLARD R., ESCAFFRE A. M., 1975. Identification des stades de la spermatogenèse de la truite fario d'après la morphologie des gonades et la spermiation. Bull. Fr. Pisci., 256, 111-118.

BILLARD R., FOSTIER A., WEIL C., BRETON B., 1982. Endocrine control of spermatogenesis in teleost fish. Can. J. Fish. Aquat. Sci., 39, 65-79.

BRETON B., PRUNET P., REINAUD P., 1978. Sexual differences in salmon gonadotropin. Ann. Biol. anim. Bioch. Biophys., 18, 759-765.

CALLARD G. V., JEFFREY A. P., MAK P., CANICK J. A., 1985. Stage-dependent changes in steroidogenic enzymes and estrogen receptors during spermatogenesis in the testis of the dogfish, Squalus acanthias. Endocrinology, 117, 1328-1335.

DEPECHE J., SIRE O., 1982. In vitro metabolism of progesterone in the testis of the rainbow trout, Salmo gairdneri Rich., at different stages of spermatogenesis. Reprod. Nutr. Dévelop., 22, 427-438.

DORRINGTON J. H., FRITZ I. B., ARMSTRONG D. T., 1978. Control of testicular estrogen synthesis. Biol. Reprod., 18, 55-64.

FOSTIER A., LE GAC F., LOIR M., 1987. Steroids in male reproduction. In Proc. 3rd Int. Symp. on Reproductive physiology of fish, St John's, Canada.

HUANG F. L., CHANG Y. S., 1980. The gonadotropic stimulation of androgen production on carp testis in vitro. Proc. nat. Counc. Roc., 4, 392-400.

IDLER D. R., NG T. B., 1983. Teleost gonadotropins : isolation, biochemistry and function, 187-221 In HOAR W. S., RANDALL D. J., DONALDSON E. M., Fish physiology IX, part A. New York Acad. Press.

INANO H., NAKANO H., SHIKITA M., TAMAOKI B. I., 1967. The influence of various factors upon testicular enzymes related to steroidogenesis. Biochim. Biophys. Acta, 137, 540-548.

JOHNSON A. R., HOLMES S. D., LIPSHULTZ L. I., SMITH R. G., 1985. Rapid method for quantitation of androgen binding protein in Sertoli cell cultures and its use for measurement of binding kinetics. J. Steroid Biochem., 22, 9-14.

KAWAUCHI H., SUZUKI K., NAGAHAMA Y., ADACHI S., NAKAIY., 1986. Occurence of two distinct gonadotropins in shum salmon pituitary, 338-390. In YOSHIMURA F., GORBMAN A., Pars distalis of the pituitary gland. Structure, function and regulation, Elsevier Sci. Publ.

LE GAC F., BRETON B., BOUGOUSSA M., 1985. In vitro studies on binding and action of s-GtH on the trout (Salmo gairdneri) testis. In Fish culture Proc. 7th Conf. Eur. Soc., comp. Physio/. Biochem., Barcelona (ab10).

LE GAC F., BRETON B., BOUGOUSSA M., 1988. Gonadotropic hormone (GtH) receptors in the testis of the trout Salmo gairdneri. In vitro studies. Fish Physiol. Biochem., 5, $n^{o}$ (in press). 
LE GAC F., FOSTIER A., 1987. Binding and action of s-GtH on rainbow trout testis at various stages of gametogenesis. In Proc. 3rd Int. Symp. on Reproductive physiology of fish. St John's, Canada.

LE GAC F., FOUCHER J. L., 1987. Androgen Binding protein in teleost testis (Sa/mo gairdneri). In Proc. 3rd Int. Symp. on Reproductive physiology of fish, St John's, Canada.

LE PRÊTRE S., 1985. Régulation de la synthèse de 17 $\alpha$-hydroxy-20ß-dihydroprogesterone dans le testicule de truite arc-en-ciel. Thèse de $3^{e}$ cycle. Univ. Pierre et Marie Curie, Paris.

LOFTS B., 1987. Testicular function, 283-325. In NORRIS D. O., JONES R. E., Hormones and reproduction in fishes, amphibian and reptiles. Plenum Press, New York and London.

LOIR M., 1987. Primary cultures of somatic testicular cells in the rainbow trout. In BRETON B., ZOHAR Y., Coll. I.N.R.A.. Reproduction chez les poissons. Bases fondamentales et appliquées en endocrinologie et génétique.

LOIR M., 1988. Trout Sertoli and Leydig cells : isolation, separation and culture. Gamete Res., 20, (in press).

NAGAHAMA Y., 1987. Gonadotropin action on gametogenesis and steroïdogenesis in teleost gonad. Zool. Sci., 4, 209-222.

NG T. B., IDLER D. R., 1980. Gonadotropic regulation of androgen production in flounder and salmonids. Gen. comp. Endocrinol., 42, 25-28.

PARVINEN M., NIKULA H., HUHTANIEMI I., 1984. Influence of rat seminiferous tubules on Leydig cell testosterone production in vitro, Mol. cell. Endocr., 37, 331-336.

PICKFORD G. E., ATZ J. W., 1957. The physiology of the pituitary gland of fish. New York, Zool. Soc. New York, p. 613.

POINTIS G., LATREILLE M. T., 1987. Catecholamine induced stimulation of testosterone production by Leydig cells from fetal mouse testis. J. Reprod. Fert., 80, 321-326.

RISBRIDGER G. P., JENKIN G., de KRESTER D. M., 1986. The interaction of hCG, hydroxysteroids and interstitial fluid on rat Leydig cell steroïdogenesis in vitro. J. Reprod. Fert., 77, 239-245.

RITZEN E., FRENCH F. S., WEDDINGTON S. G., NAYFEH S. N., HANSSON V., 1974. Steroid binding in polyacrylamide gels, quantitation at steady state conditions. J. biol. Chem. 249, 6597-6604.

SAAD A., DEPEECHE J., 1987. In vitro effect of salmon gonadotropin on the testicular synthesis of androgens and of a progestin, $17 \alpha$-hydroxy-20 $\beta$-dihydroprogesterone, in the rainbow trout (Salmo gairdneri). Reprod. Nutr. Dévelop., 27, 423-439.

SCHULZ R., BLUM V., 1987. Gonadotropin stimulated androgen secretion of rainbow trout (Salmo gairdneri Richardson) testis in vitro. Comp. Biochem. Physiol., 88A, 49-54.

SINGH H., GRIFFITH R. W., TAKANASHI A., KAWAUCHI H., THOMAS P., STERGEMAN J. J., 1987. Effect of salmon growth hormone on steroidogenesis in mummichog. Fundulus heterochitus. In Proc. 3rd Int. Symp. on Reproductive physiology of Fish, St John's, Canada.

TAHKA K. M., 1986. Current aspects of Leydig cell function and its regulation. J. Reprod. Fert., 78. 367-380.

TINDALL D. J., MEANS A. R., 1980. Properties and hormonal regulation of androgen binding proteins, 295-327. In THOMAS J. A., SINGHAL R. L., Advances in sex hormone research, vol. 4, Urban and Schwvarzenberg, Baltimore-Munich.

UEDA M., KAMBEGAWA A., NAGAHAMA Y., 1984. In vitro 11 -ketotestosterone and $17 \alpha-20 \beta$ dihydroxy-4-pregnen-3-one production by testicular fragments and isolated sperm of rainbow trout, Salmo gairdneri. J. exp. Zool., 235, 435-439.

VAN DER KRAAK G., PETER R. E., KAWAUCHI, 1987. Immunological and biological characteristics of two glycoprotein gonadotropins from the carp pituitary. In Proc. 3rd Int. Symp. on Reproductive physiology of fish, St John's, Canada.

VERHOEVEN G., CAILLEAU J., VAN DER SCHUEREN B., CASSIMAN J. J., 1986. The dynamics of steroid and Adenosine $3^{\prime}, 5^{\prime}$-cyclic monophosphate output in perifused interstitial cell aggregates derived from prepubertal rat testis. Endocrinology, 119, 1476-1488.

YAMAZAKI F., DONALDSON E. M., 1969. Involvement of gonadotropin and steroid hormones in the spermiation of the goldfish (Carassius auratus). Gen. comp. Endocrinol., 12, 491-497. 